\title{
A rapid clay-mineral change in the earliest Priabonian of the North Sea Basin?
}

\author{
R. Saeys, A. Verheyen \& N. Vandenberghe ${ }^{1}$
}

K.U. Leuven, Historical Geology, Redingenstraat 16, B-3000 Leuven, Belgium

1 corresponding author: noel.vandenberghe@geo.kuleuven.ac.be

Manuscript received: February 2004; accepted: August 2004

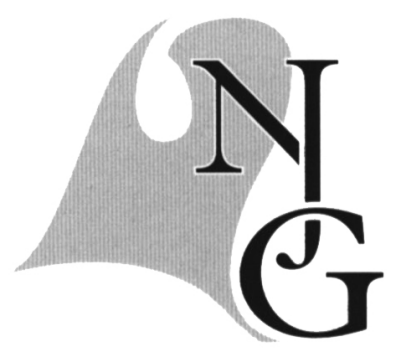

\begin{abstract}
In the Eocene to Oligocene transitional strata in Belgium, clay mineral associations vary in response to the climatic evolution and to tectonic pulses. Decreasing smectite to illite ratios and the systematic occurrence of illite-smectite irregular interlayers are consequences of a cooling climate. A marked increase in kaolinite content occurs just after a major unconformity formed at the Bartonian/Priabonian boundary and consequently is interpreted as resulting from the breakdown of uplifted saprolites.
\end{abstract}

Keywords: clay minerals, Paleogene, North Sea Basin

\section{Introduction}

The International Geological Correlation Program Project No 124 integrated the Cenozoic stratigraphic data of the North Sea Basin, which were dispersed at that time in the literature, and the traditions of the different countries around the North Sea (Vinken, 1988). Since this study, it has become known that broadly speaking the Eocene sediments in the basin have a clay mineralogy dominated by smectite whilst in contrast the Oligocene sediments have a clay mineralogy characterized by mixtures in which illite and kaolinite are prominently present (Quinif et al., 1983; Nielsen, 1988; Pearson \& Small, 1988; Pearson, 1990).

The precise stratigraphic position of this transition however is poorly documented and also the reasons for this general change in clay mineral associations in the North Sea Basin remain debatable. The objective of the present study is to better define the timing of this change in clay mineral composition and to discuss its cause in the light of the present knowledge of the paleoclimatic and paleodynamic evolution of the area.

\section{Stratigraphy of the Eocene to Oligocene in the southern North Sea}

The study of the cored Doel 2b well, north of Antwerp in Belgium, has documented the Bartonian, Priabonian and Early Rupelian transition layers by lithostratigraphy, nannoplankton and dinoflagellate biostratigraphy, and by geophysical well logs (Vandenberghe et al., 2003). Verheyen (2003) has tested the regional validity of the subdivisions established in the Doel $2 \mathrm{~b}$ well by examining the geophysical well logs, the lithology and the biostratigraphic data of more than fifty wells in North Belgium. Some key wells, their well-log based correlation and their stratigraphic interpretation are represented in the regional model on Fig. 1. This regional correlation is documenting the Eocene to Oligocene transition in the type area for the southern North Sea Basin stratigraphy.

A main regional stratigraphic feature in that time interval is the unconformity underlying the Tongeren Group sediments in northeast Belgium. Log correlation and biostratigraphic calibration demonstrate that this 

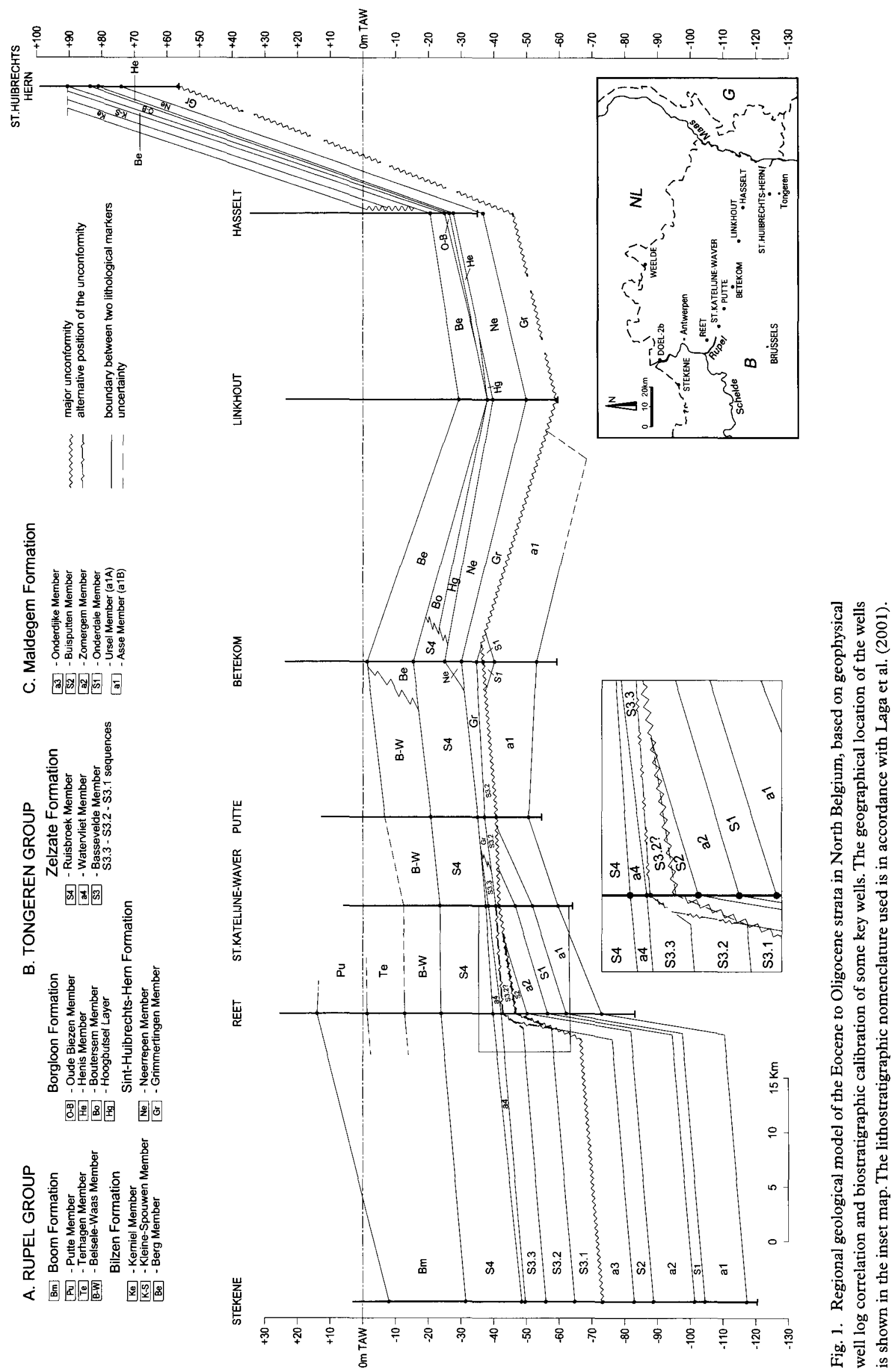
unconformity continues westward into the boundary between the latest Bartonian (a3 coded Onderdijke Member on Fig.1) and earliest Priabonian (S3.1 coded lower part of the Bassevelde Member on Fig.1). In that area the Priabonian is mainly represented by the Bassevelde Sands; it was demonstrated however, that these sands in fact consist of three sequences, respectively belonging to the NP18 (S3.1), NP19-20 (S3.2) and NP21 (S3.3) biozones (Vandenberghe et al. 2003). The youngest sequence (S3.3) includes a clay layer at the top (a4 coded Watervliet Member on Fig. 1). Only this youngest sequence has a large geographical extension and the two older Bassevelde sequences (S3.1 and S3.2) have a geographically limited occurrence, with S3.2 extending more southeastwards than the S3.1 sequence (Fig. 2). The upper sequence S3.3 in fact connects to the east with the marine part of the Tongeren Group (Sint-Huibrechts-Hern Formation, consisting of Grimmertingen and Neerrepen Members) of the same NP21 age (Fig. 1). This sequence extends southeastwards even over the Ardennes (Vandenberghe et al. 1998, Vandenberghe et al., this volume) and is of earliest Oligocene age, based especially on dinoflagellate content (Vandenberghe et al., 2003).

The relative low sea level between this last sequence (Bassevelde S3.3 and marine Tongeren Group) and the next younger sequence ( $\mathrm{S} 4$ and $\mathrm{Bm}$ on Fig.1) is very pronounced. Rising sea level subsequently forms lowstand deposits (S4 coded Ruisbroek sand and continental Borgloon Formation of the Tongeren Group, both in the NP22 biozone), and transgressive Boom Clay which already contains NP23 flora at its base. The low sea level coincides with the sudden shift to a much colder oxygen isotope signature (De Man et al., this volume).

\section{Clay mineral analysis of the Eocene to Oligocene sediments in North Belgium}

Based on the stratigraphic analysis discussed above and shown in Fig. 1, eight cored boreholes were selected for clay mineral determinations (Fig. 2). More than 200 samples were analyzed (Saeys, 2003); the sampling positions were chosen to have clay mineral successions in stratigraphic reference wells, such as the Doel $2 b$ and the Sint-Huibrechts-Hern wells, and to confirm these successions and their position with respect to biostratigraphic data in other wells (Fig. 2).

Clay mineral analysis has been performed using the classical XRD analysis of oriented slides after airdrying, ethylene glycol saturation and heating treatments. The clay minerals are identified using the procedures outlined in Thorez $(1975,1976)$.
For the purpose of this study, a simplified semiquantitative analysis is made based on peak height measurements and applying correction factors with respect to illite (smectite 0.25 , kaolinite 0.7 , chlorite 0.34 ). Clay mineral associations in the overlying Rupelian Boom clay are known in detail from the studies of Laenen (1997) and Vandenberghe \& Laenen (1999).

The results in the different wells being similar (Saeys, 2003), three wells are choosen for a representative composite section in Fig. 3, on which illitesmectite irregular interlayers are included in the illite group. It appears that the Late Lutetian and Bartonian sediments are systematically dominated by smectite (swelling till $17 \AA$ ) and have lesser quantities of illite and even less kaolinite. At the base of the oldest Priabonian sequence (the S3.1 lower part of the Bassevelde Sands), a rapid decrease in smectite occurs in favour of a sudden appearance of significant amounts of kaolinite, and without a significant change in the amount of illite. Illite-smectite random interlayers become also systematically associated with illite during the Priabonian whereas in the older sediments their presence seems more irregular. On Fig. 3, illite-smectite random interlayers are included in the illite group as their content rarely exceeds $10 \%$ of the total clay minerals and therefore does not influence the trends appearing in Fig. 3. Chlorite is present in both intervals but in small quantities.

The Priabonian clay mineral association of smectite $(20-25 \%)$, kaolinite $(30-35 \%)$, illite $(25-30 \%)$ and illite-smectite irregular interlayers (10-15\%) also compares well to the clay mineral association found in the overlying Rupelian Boom Clay (see also Laenen, 1997).

\section{Climatic and tectonic influences on the clay mineral associations}

In the oceanic domain outside the North Sea Basin, similar changes in clay mineral composition between smectite-dominated Eocene and illite-dominated Oligocene sediments have been reported from both the South and the North Atlantic Ocean drilling program (Chamley, 1989; Robert, 1980). Such a general change of an Eocene smectite-dominated clay mineral association to a more varied association with important illite quantities around the EoceneOligocene boundary strongly suggests that a general change in weathering conditions must have taken place. Therefore, a major contribution of altered volcanics (Pearson, 1990) to the North Sea Eocene smectite is less likely. The change in weathering clay products obviously can be associated with the general 
岕

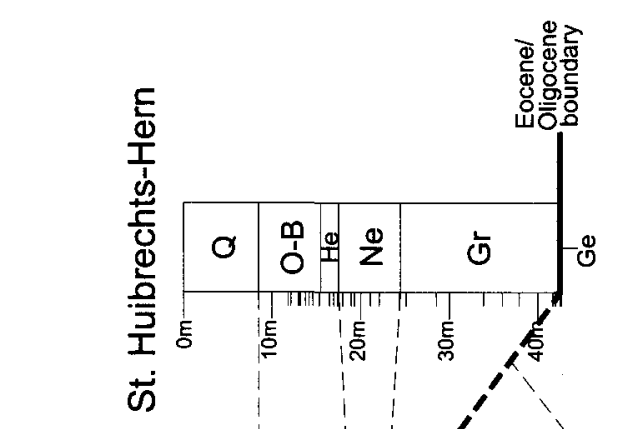

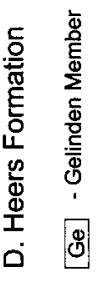
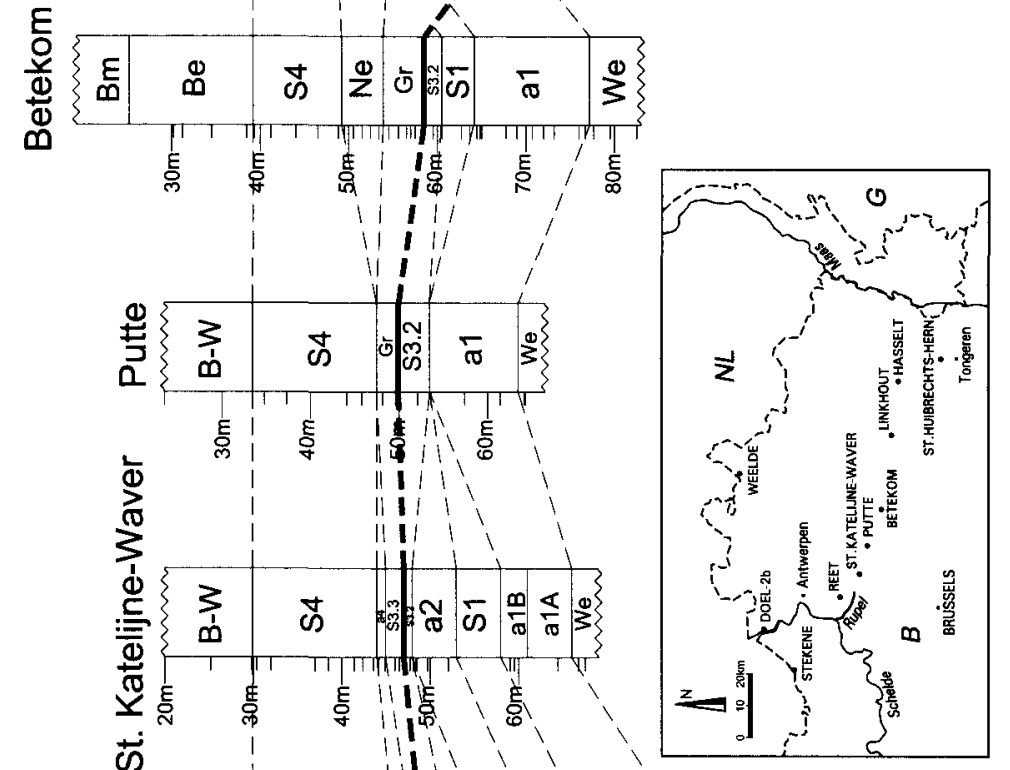

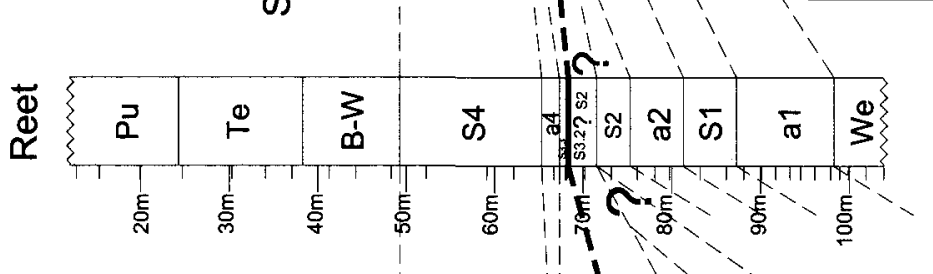

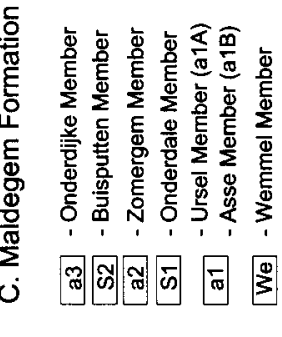

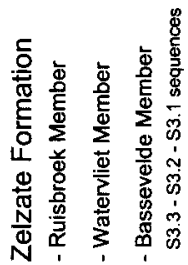

号岛岛

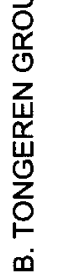

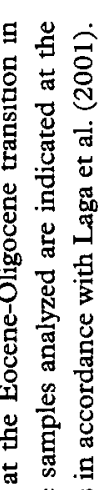

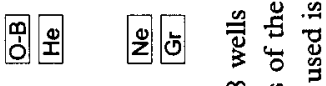

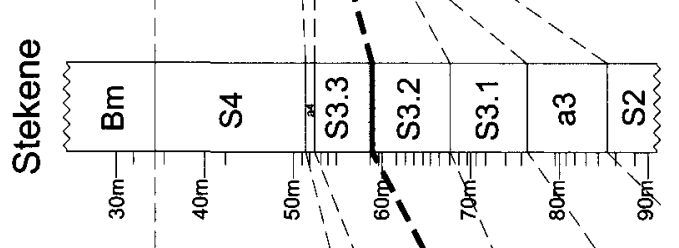

范总壱

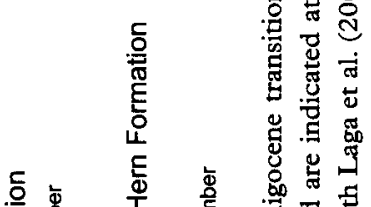

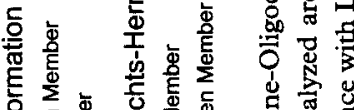

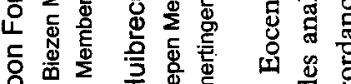

政

인

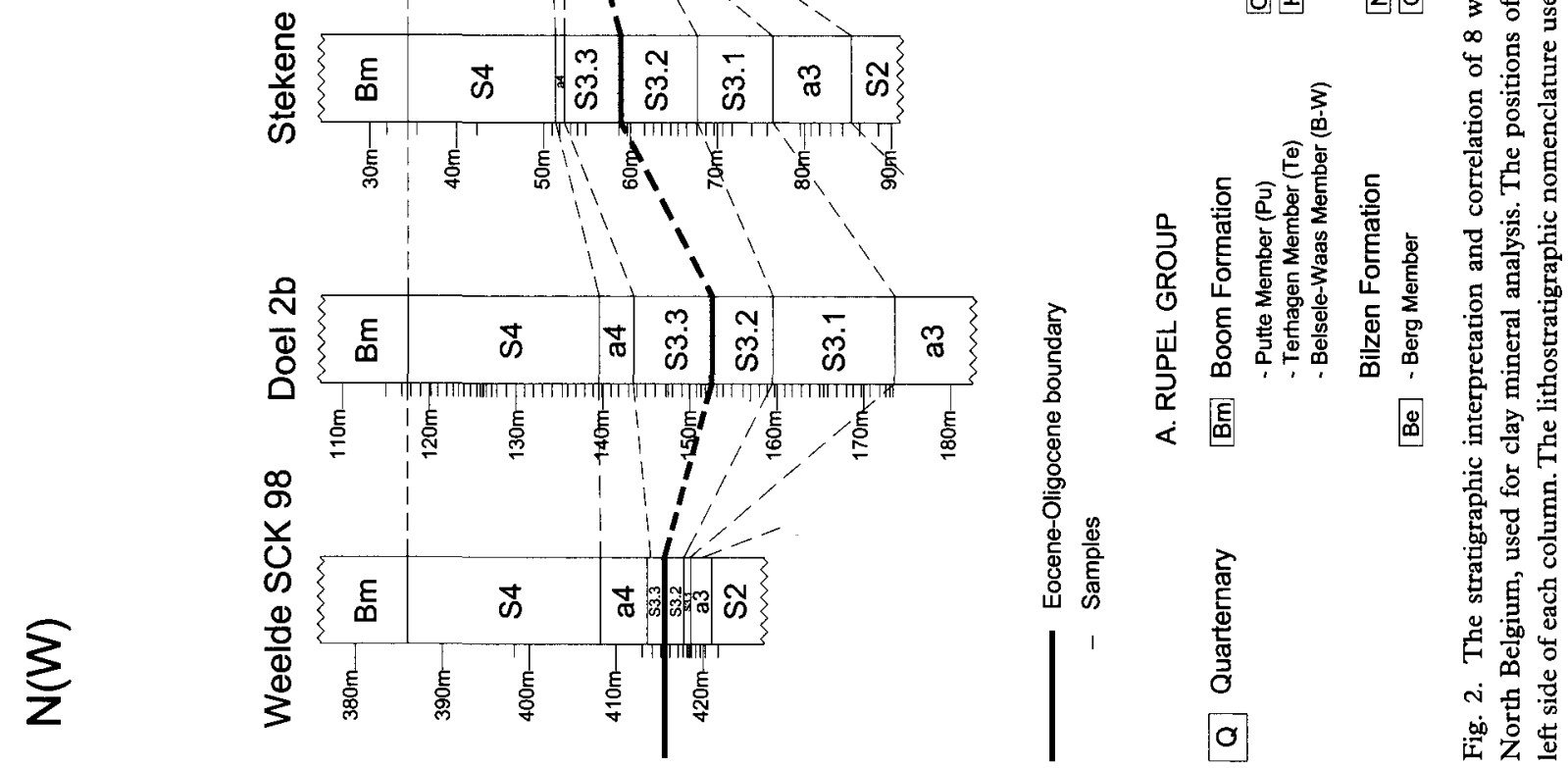


change from a humid and warm Eocene climate to a cold Oligocene climate as is demonstrated by the oxygen isotope data (Zachos et al., 1994). Since about the latest Ypresian, a gradual cooling trend started and a sudden cooling occurred in the earliest Oligocene. Paleobotany data in the area investigated show a clear seasonality in the latest Ypresian and a still warm but dryer climate in the beginning of the Lutetian (Quinif et al., 1983). Superposed on the general cooling trend, a marked warming pulse occurs at the Lutetian-Bartonian transition, and also in the Early Priabonian a renewed warming occurs (Boharty \& Zachos, 2003).

Illite and small amounts of chlorite are consistently present in the Eocene-Oligocene transitional interval. They point to a continuous contribution of almost unaltered particles derived from the older late-diagenetic and metamorphic rocks and slate belts around the basin (e.g. from the Ardennes). Reduced weathering intensity in the cooler climate is probably the main reason. The apparent increase in illite to smectite ratio (illite-smectite random interlayers content remains rather constant) in the latest Bartonian, Priabonian and earliest Rupelian (Fig.3) is probably also related to the Pyrenean uplift (unconformity at the Bartonian-Priabonian boundary on Fig. 1) and also to the uplift and relative low sea level, with consequent increase of erosion, at the base of the sequence S4-Bm on Fig. 1 (for details see Vandenberghe et al., 2002).

During the Eocene humid and warm climate mainly smectitic clays are produced in the soils, subsequently reflected in the Eocene marine detrital sediments. When weathering becomes less intense in the cooler Early Oligocene, the weathering does not lead any longer to mainly smectite; instead a less mature weathering mixture is produced of smectite and illite-smectite irregular interlayers, explaining the systematic occurrence of illite-smectite random interlayers since the Priabonian in our sections.

Obviously, the general appearance of kaolinite in the Oligocene does not fit the weaker chemical weathering in a colder climate. Therefore, the jump to higher kaolinite content in the Early Priabonian lower Bassevelde sand (S3.1) can not be related to the short warming pulse at that time, before the onset of major cooling above the top of the Bassevelde sands (S3.3). The kaolinite jump just above a major unconformity however, suggests that kaolinite is delivered to the basin by uplifting older kaolinite-rich saprolites that had developed in earlier Paleogene and probably Mesozoic time. Such deeply weathered kaolinite bearing saprolites have developed on top of the Ardennes (Yans et al., 2003).

Laenen (1997, 1998) and Vandenberghe \& Laenen (1999), however, have demonstrated that the main amount of kaolinite in the Early Rupelian of the southern North Sea was derived from the northern North Sea. In that northern area, especially Fennoscandinavia, major uplift is known to have started at the beginning of the Oligocene (Faleide et al., 2002, p. 251; Huuse, 2002) and continued as a major uplift during the late Oligocene to Pliocene time (Doré et al., 1998). Quinif et al. (1983) also see the origin of the kaolinite in the breakdown of older ferralithic soils but these authors suggested that the climate degradation was itself responsible for the breakdown of the vegetation cover initiating the erosion of the soils.

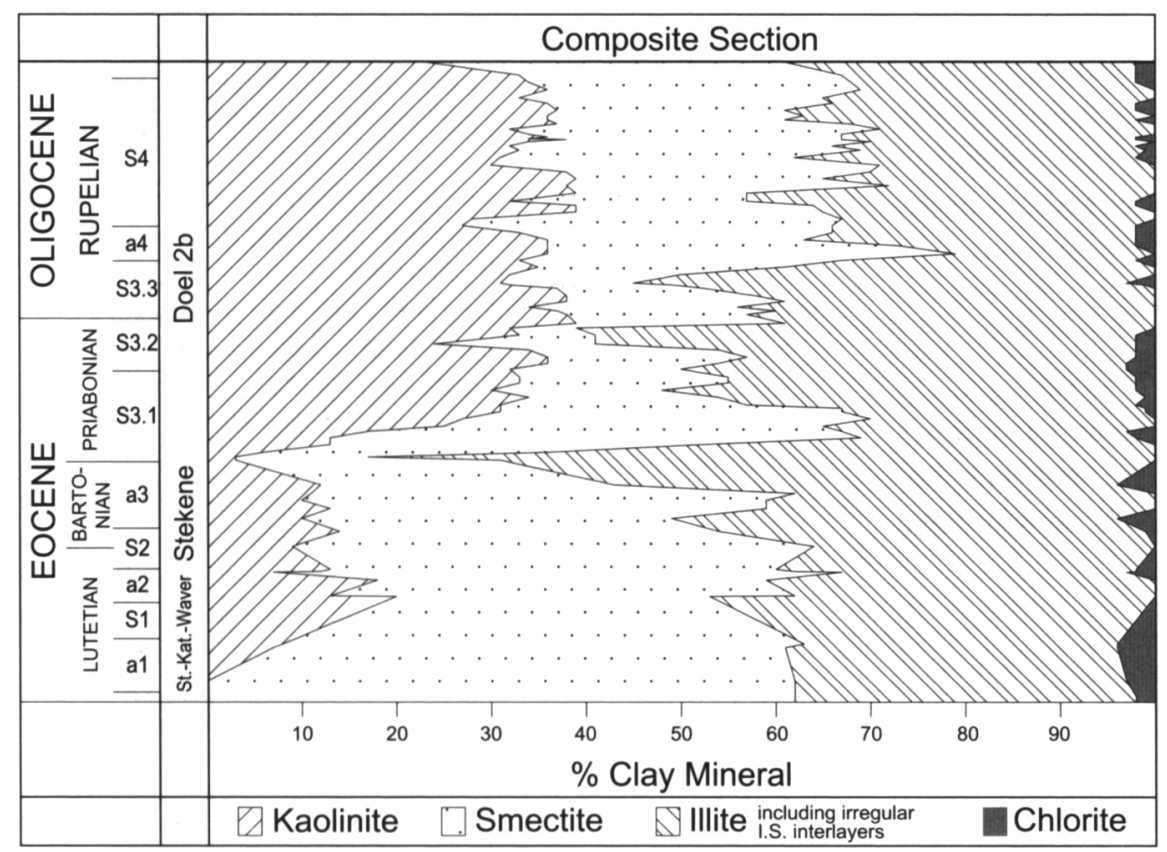

Fig. 3. Composite section of the clay mineral composition of the successive lithostratigraphic units from Lutetian till Rupelian in the Sint-Kathelijne-Waver, Stekene and Doel $2 \mathrm{~b}$ wells; the data are representative for the clay mineral data obtained in the 8 wells examined and shown in Fig. 2. The symbols of the lithostratigraphic units are the same as in Figs. $1 \& 2$. 
They see an argument in the smaller quantities of kaolinite appearing already in the Lutetian. However, at the end of the Ypresian and the beginning of the Lutetian starts also an important uplift of the ArtoisBrabant-Ardennes axis (Blondeau et al., 1965; Pomerol, 1975), probably initiating the breakdown of the older kaolinite bearing ferralithic soils leading to the admixture of kaolinite in the marine sediments along the coasts bordering the uplifted blocs.

\section{Conclusions}

A detailed regional geological study has demonstrated an important tectonic event at the BartonianPriabonian boundary. During the Priabonian two sandy sequences (two lower Bassevelde sand units) with a limited extension have been deposited in North Belgium. In the earliest Oligocene a very widespread transgression occurred documented by marine Tongeren Group sediments, a top part of the Bassevelde sands and the Watervliet clay (NP 21 sequence). Between this earliest Oligocene sequence and the next sequence occurs a major sea-level fall coinciding with a major cooling demonstrated by oxygen isotopes.

Clay mineral analysis shows that a sharp change occurs at the base of the lowest Priabonian sequence. A smectite and illite association below is replaced above by an association of smectite, kaolinite, illite and illite-smectite irregular interstratifications.

It is argued that the changing ratio of smectite to illite and illite-smectite irregular interlayers, represents a change in weathering conditions accompanying the climate transition from humid and warm to cold. The rather sudden kaolinite increase is the result of the erosion of older soils and saprolites, uplifted in areas surrounding the northern part of the North Sea since the end of the Eocene and beginning of the Oligocene. Smaller quantities of kaolinite in the Lutetian and Bartonian sediments are probably brought in the basin by already earlier tectonic uplift of the London-Artois-Brabant bloc.

\section{Acknowledgments}

The research has benefited from the financial support of the F.WO. (G.0093.01N/E8). The referees are thanked for their constructive remarks which have improved the original manuscript.

\section{References}

Blondeau, A., Cavelier, C., Feugueur, L. \& Pomerol, C., 1965. Stratigraphie du Paléogène du Bassin de Paris en relation avec les bassins avoisinants. Bulletin Société Géologique de France, 7 ième série $7: 200-221$.

Bohaty, M. S. \& Zachos, J.C., 2003. Significant Southern Ocean warming event in the late middle Eocene. Geology 31: 1017-1020.

Chamley, H., 1989. Clay Sedimentology. Springer-Verlag (Berlin): 623pp.

De Man, E., Ivany, L. \& Vandenberghe, N., (this volume). Stable oxygen isotope record of the Eocene-Oligocene transition in NE Belgium. Netherlands Journal of Geosciences / Geologie en Mijnbouw.

Doré, A.G., Lundin, E.R., Jensen, L.N., Birkeland, Ø., Eliasen, Ø. \& Fichler, C. 1998. Principal tectonic events in the evolution of the northwest European Atlantic margin. In: Fleet, A.J. \& Boldy, S.A.R. (eds): Petroleum Geology of Northwest Europe. Geological Society London: 41-61.

Faleide, J.I., Kyrkjebø R., Kjennerud, T., Gabrielsen R.H., Jordt, H., Fanavoll, S. \& Bjerke, M.D., 2002. Tectonic impact on sedimentary processes during Cenozoic evolution of the northern North Sea and surrounding areas. In: Doré, A.G., Cartwright, J.A., Stoker, M.S., Turner, J.P. \& White, N. (eds): Exhumation of the North Atlantic Margin: Timing, Mechanisms and Implications for Petroleum Exploration. Geological Society, London, Special Publication 196: 235-269.

Huuse, M., 2002. Cenozoic uplift and denudation of southern Norway: insights from the North Sea Basin. In: Doré, A.G., Cartwright, J.A., Stoker, M.S., Turner, J.P. \& White, N. (eds): Exhumation of the North Atlantic Margin:Timing, Mechanisms and Implications for Petroleum Exploration. Geological Society London, Special Publication 196: 209-233.

Laenen, B., 1997. The Geochemical Signature of Relative Sea-level Cycles Recognized in the Boom Clay. Doctoral thesis K.U. Leuven ( 3 volumes): $523 \mathrm{pp}$.

Laenen, B., 1998. The geochemical signature of relative sea-level cycles recognized in the Boom Clay. Aardkundige Mededelingen (Leuven University Press) 9: 61-82.

Laga, P., Louwye, S. \& Geets, S., 2001. Paleogene and Neogene lithostratigraphic units (Belgium). Geologica Belgica (Brussel) 4: 135-152.

Nielsen, O.B., 1988. The clay mineralogy in the eastern and southeastern parts of the Tertiary North Sea Basin. In: Vinken, R. (ed): The Northwest European Tertiary Basin. Geologisches Jahrbuch A 100: 141-143.

Pearson, M.J., 1990. Clay mineral distribution and provenance in Mesozoic and Tertiary mudrocks of the Moray Firth and northern North Sea. Clay Minerals 25: 519-541.

Pearson, M.J. \& Small, J.S., 1988. Illite-smectite diagenesis and paleotemperature in northern North Sea Quaternary to Mesozoic shale sequence. Clay Minerals 23: 109-132.

Pomerol, C., 1975. Stratigraphie et paléogéographie. Ere Cénozoique (Tertiaire et Quaternaire). Doin: $269 \mathrm{pp}$.

Quinif, Y., Mercier, M., Roche, E. \& Dupuis, C., 1983. Essai de reconstitution géodynamique du Paléogène du bassin belge à partir des données de la minéralogie des argiles, de la géochimie des radioéléments $\left(\mathrm{U}, \mathrm{Th}, \mathrm{K}_{2} \mathrm{O}\right.$ ) et de la palynologie. Comptes Rendus de l'Académie des Sciences (Paris) II 296: 1621-1624.

Robert, C., 1980. Climats et courants Cénozoïques dans l'Atlantique Sud d'après l'étude des minéraux argileux (legs 3,39 et 40 DSDP). Oceanologica Acta 3 (3): 369-376. 
Saeys, R., 2003. De 'kaoliniet-smectiet'-sprong in de EoceenOligoceen overgangslagen van het zuidelijk Tertiair Noordzeebekken. Licentiaatsverhandeling K.U. Leuven: 84 pp.

Thorez, J., 1975. Phyllosilicates and clay minerals. A laboratory handbook for their X-ray diffraction analysis. G. Lelotte (Dison): 579 pp.

Thorez, J., 1976. Practical identification of clay minerals. G. Lelotte (Dison): 90 pp.

Vandenberghe, N. \& Laenen, B., 1999. The impact of relative sealevel on the clay mineralogy of the Boom Clay Formation (Rupelian-Belgium). Conference of the European Clay Groups Association, Euroclay 1999 (Kraków), Abstracts: 142.

Vandenberghe, N., Laga, P., Steurbaut, E., Hardenbol, J. \& Vail,P.R., 1998. Tertiary sequence stratigraphy at the southern border of the North Sea Basin in Belgium. In: de Graciansky, P.C., Hardenbol, J., Jacquin, T. \& Vail, P.R. (eds): Mesozoic and Cenozoic Sequence Stratigraphy of European Basins. Society for Sedimentary Geology (SEPM) Special Publication 60: 261-288.

Vandenberghe, N., Herman, J. \& Steurbaut, E., 2002. Detailed Analysis of the Rupelian Ru-1 Transgressive Surface in the Type Area (Belgium). In: Gürs, K. (ed): Northern European Cenozoic Stratigraphy. Proceedings of the 8th Biannual Meeting of the Regional Committees RCNNS/RCNPS (northern Paleogene and Neogene Stratigraphy). Landesamt für Natur und Umwelt des Landes Schleswig-Holstein (Flintbek): 67-81.
Vandenberghe, N., Brinkhuis, H. \& Steurbaut, E., 2003. The Eocene/Oligocene Boundary in the North Sea Area: A sequence Stratigraphic Approach. In: Prothero, D.R., Ivany, L.C. \& Nesbitt, E.A. (eds): From Greenhouse to Icehouse. The Marine Eocene-Oligocene Transition. Columbia University Press: 419437.

Vandenberghe, N., Van Simaeys, S. \& Steurbaut, E., this volume. Stratigraphic architecture of the Late Cretaceous and Cenozoic at the southern border of the North-Sea Basin in Belgium. Netherlands Journal of Geosciences/Geologie en Mijnbouw.

Verheyen, A., 2003. Geofysische karakterisatie en correlatie van de Eoceen-Oligoceen overgangslagen in België. Licentiaatsverhandeling K.U. Leuven: 119 pp.

Vinken, R. (ed), 1988. The Northwest European Tertiary Basin, Results of the International Geological Correlation programme Project No 124. Geologisches Jahrbuch, A 100: 508 pp.

Yans, J., Quesnel, F. \& Dupuis, C., 2003. Meso-cenozoic paleoweathering of the Haute-Lesse area (Ardenne-Belgium). In: Quesnel, F. (coord.): Paleoweathering and Paleosurfaces in the Ardenne-Eifel region. Géologie de la France $N^{\circ} 1$. Field trip guides: $3-10$.

Zachos J.C., Stott L.D. \& Lohmann K.C., 1994. Evolution of early Cenozoic marine temperatures. Paleoceanography 99: 353-387. 